\title{
Influence of Endothelin 1 Receptor Blockers and a Nitric Oxide Synthase Inhibitor on Reactive Oxygen Species Formation in Rat Lungs
}

\author{
P. KLENIEWSKA ${ }^{1}$, A. GORĄCA ${ }^{1}$ \\ ${ }^{1}$ Experimental and Clinical Physiology, Department of Cardiovascular Physiology, Medical \\ University of Lodz, Poland
}

Received November 14, 2015

Accepted March 18, 2016

On-line July 15, 2016

\section{Summary}

This study was designated to estimate protective role of ETA and ETB receptor antagonist against endothelin 1 (ET-1)-induced oxidative stress in lungs and determine whether these effects are mediated by nitric oxide (NO) synthase. Experiments were performed on Wistar rats divided into the following groups: I - saline (0.9 \% NaCl); II - ET-1 (3 $\mu \mathrm{g} / \mathrm{kg}$ b.w.), III - BQ123 $(1 \mathrm{mg} / \mathrm{kg}$ b.w.) + ET-1 (3 $\mu \mathrm{g} / \mathrm{kg}$ b.w.), IV - BQ788 (3 mg/kg b.w.) + ET-1 (3 $\mu \mathrm{g} / \mathrm{kg}$ b.w.), V - N-nitro-L-arginine methyl ester (L-NAME) $(5 \mathrm{mg} / \mathrm{kg}$ b.w.) + ET-1 (3 $\mu \mathrm{g} / \mathrm{kg}$ b.w.). ETA and ETB receptor antagonists or L-NAME were administered $30 \mathrm{~min}$ before ET-1 injection. The levels of the following substances were measured in the lungs homogenates: thiobarbituric acid reactive substances (TBARS), hydrogen peroxide $\left(\mathrm{H}_{2} \mathrm{O}_{2}\right)$, reduced glutathione (GSH) and tumor necrosis factor-alpha (TNF-a). The results showed that ET-1 significantly increased TBARS, $\mathrm{H}_{2} \mathrm{O}_{2}$ (respectively: $p<0.001, p<0.02)$ and TNF-a levels $(p<0.02)$ and decreased the GSH level $(p<0.01)$ vs. control group. On the other hand, prior administration of ETA receptor blocker (BQ123) significantly attenuated TBARS $(p<0.01), \mathrm{H}_{2} \mathrm{O}_{2}(p<0.02)$, TNF-a $(p<0.02)$ and increased GSH $(p<0.02)$ levels vs. ET-1. However, prior administration of ETB receptor blocker $\mathrm{BQ788}$ did not cause significant changes in the: TBARS, $\mathrm{H}_{2} \mathrm{O}_{2}$ and TNF-a $(p>0.05)$ levels, but significantly increased the GSH level and GSH/GSSG ratio $(p<0.05)$. Administration of L-NAME significantly attenuated TBARS $(p<0.001), \mathrm{H}_{2} \mathrm{O}_{2}(p<0.05)$, TNF- $a(p<0.01)$ and increased GSH $(p<0.05)$ levels vs. ET-1. In conclusion, we demonstrated that ET-1 induced oxidative stress in the lungs is mediated by ETA receptors. ETA receptor blockage inhibited generation of free radicals and TNF-a and ameliorated antioxidant properties.
Moreover, generation of reactive oxygen species is mediated by NOS in the lungs.

\section{Key words}

Endothelin 1 • Endothelin receptor blockers • L-NAME • Lungs

\section{Corresponding author}

P. Kleniewska, Experimental and Clinical Physiology, Department of Cardiovascular Physiology, Medical University of Lodz, Mazowiecka 6/8 Street, PL 92-215 Lodz, Poland. E-mail: paulina.kleniewska@umed.lodz.pl

\section{Introduction}

Endothelins are a family of peptides (ET-1, ET-2, and ET-3) which have different biological activities in both vascular and non-vascular tissues. Endothelin-1 (ET-1) is a 21-amino-acid polypeptide produced primarily by vascular endothelial cells and is characterized as a powerful smooth muscle vasoconstrictor and mitogen (Galie et al. 2004). In mammals, ET-1 binds to specific G protein-coupled membrane receptors, ETA and ETB. ETA receptors are found on smooth muscle cells and mediate contraction, cell growth, adhesion, fibrosis and thrombosis. ETB receptors are localized on endothelial cells and to some extent in smooth muscle cells and macrophages and mediate vasodilatation via nitric oxide (NO) and prostacyclin generation (Schiffrin 2001). Increasing evidence demonstrates that this peptide stimulates superoxide anion production in vascular smooth muscle 
cells (VSMC) (Laplante et al. 2005), isolated arteries (Galie et al. 2004, Loomis et al. 2005, Sedeek et al. 2003), veins (Li et al. 2003a, Thakali et al. 2005), lungs (Hsu et al. 2010), and heart (Lund et al. 2005). Some studies have shown that chronic intravenous ET-1 infusion increased vascular superoxide anions production and plasma TBARS level (Yao et al. 2004). Also "in vitro" studies have demonstrated that ET-1 increases ROS formation in endothelial cells ( $\mathrm{Li}$ et al. 2003b, Sedeek et al. 2003). Another authors also confirmed that an increase in the superoxide level was associated with a decrease in NOS activity (Hsu et al. 2010) and developed hypertension (Sullivan et al. 2006, Thakali et al. 2005).

Nitric oxide (NO) is a key regulator of cardiovascular function and is generated by a family of nitric oxide synthase (NOS) enzymes or by nonenzymatic reduction in nitrite. All three isoforms of NOS, neural nNOS, inducible iNOS, and endothelial eNOS, which produce NO from L-arginine are expressed in the cardiovascular tissues (Schulz et al. 2005). NO can act as an antioxidant by inhibiting activation of xanthine oxidase (XO) (Hassoun et al. 1995) and NADPH oxidase (Yao et al. 2004), and maintaining normal O2*- / NO homeostasis. NO can interact with superoxide anion to form peroxynitrite $\mathrm{ONOO}^{-}$. Peroxynitrite can be decomposed to nitrate or can trigger an array of cytotoxic processes including lipid peroxidation and protein modification, thus modulating biological processes (Zhang et al. 2012). Under elevated superoxide anion level conditions peroxynitrite can lead to formation of hydroxyl radicals (Schulz et al. 2005). ROS and reactive forms of nitrogen (RFN) causing oxidative damage biomolecules ultimately lead to oxidative stress and cell injury.

The mechanism effect of ETA and ETB receptor blockade on generation of ROS in the lungs has not been well understood yet. In this context, we wanted to investigate protective role of endothelin receptor antagonists against ET-1 induced oxidative stress in lungs and determine whether the effects of ET-1 are mediated by NOS in the lungs.

\section{Methods}

\section{Chemicals}

Endothelin 1 (powder; a synthetic peptide with the sequence of human and porcine ET-1; powerful vasoconstrictor properties); BQ123 (cyclo-(D-Asp-Pro-
D-Val-Leu-D-Trp; selective ET-A receptor blocker a drug that blocks endothelin A receptors.); BQ788 (2,6Dimethylpiperidinecarbonyl- $\gamma$-Methyl-Leu-Nin-(Methoxycarbonyl)-D-Trp-D-Nle,N-[N-[N-[(2,6-Dimethyl-1-piperidinyl)carbonyl]-4-methyl-L-leucyl]-(methoxycarbonyl)-D-tryptophyl]-D-norleucine sodium salt; selective ET-B receptor blocker - a drug that blocks endothelin B

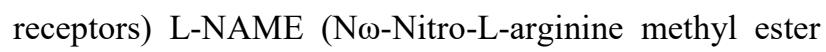
hydrochloride; an analog of arginine that inhibits NO production); thiobarbituric acid (TBA); butylated hydroxytoluene (BHT); sodium acetate trihydrate, triethanoloamine hydrochloride (TEA); 5-sulfosalicylic acid hydrate (5-SSA); 5,5'-dithio-bis (2-nitrobenzoic acid) (DTNB); $\beta$-NADPH $(\beta$-nicotinamide adenine dinucleotide phosphate); glutathione reductase (GR) and 2-vinylpyridine were obtained from Sigma-Aldrich Chemical Co. (30 Szelagowska St, 61-626) Poland). All other reagents were obtained from $\mathrm{POCH}$ (Gliwice, Poland) and were of analytical grade.

\section{Animals}

Experiments were performed on male Wistar rats weighing 200-220 g, aged 2-3 months. The animals were housed 6 per cage under standard laboratory conditions in a $12 / 12 \mathrm{~h}$ light-dark cycle (lights on at $7.00 \mathrm{AM}$ ) at $20 \pm 2{ }^{\circ} \mathrm{C}$ ambient temperature and air humidity of $55 \pm 5 \%$. All animals received a standard laboratory diet and water ad libitum. All animals were given a one-week acclimation period before the onset of the experiment. The experimental procedures followed the guidelines for the care and use of laboratory animals, and were approved by the Medical University of Lodz Ethics Committee (28/LB 520/2010).

\section{Experimental protocol} as follows:

Animals were randomly divided into five groups

$1^{\text {st }}$ group (control group, $\mathrm{n}=6$ ) received two doses of $0.2 \mathrm{ml}$ of saline, at $30 \mathrm{~min}$ interval;

$2^{\text {nd }}$ group (ET-1 group, $\mathrm{n}=6$ ) received $0.2 \mathrm{ml}$ of saline, and half an hour later the rats were injected with a single dose of ET-1 (3 $\mu \mathrm{g} / \mathrm{kg})$;

$3^{\text {rd }}$ group (BQ123+ET-1 group, $\left.n=6\right)$ were given $0.2 \mathrm{ml}$ of BQ123 $(1 \mathrm{mg} / \mathrm{kg})$, and half an hour later the rats were injected with a single dose of ET-1 $(3 \mu \mathrm{g} / \mathrm{kg})$;

$4^{\text {th }}$ group $(\mathrm{BQ788}+\mathrm{ET}-1, \mathrm{n}=6)$ received $0.2 \mathrm{ml}$ BQ788 (3 mg/kg) and $0.5 \mathrm{~h}$ later ET-1 (3 $\mu \mathrm{g} / \mathrm{kg})$;

$5^{\text {th }}$ group (L-NAME+ET-1, $\left.\mathrm{n}=6\right)$ received $0.2 \mathrm{ml}$ L-NAME (5 mg/kg) and $30 \mathrm{~min}$ later ET-1 (3 $\mu \mathrm{g} / \mathrm{kg})$. 
All reagents were injected intravenously into the femoral vein between 8.00 AM and 9.00 AM. After the administration of compounds, each group of animals was observed for a period of $5 \mathrm{~h}$. The doses used in this study were selected on the basis of reports of previous studies (Piechota-Polanczyk et al. 2012).

\section{Animal preparations}

Animals were anaesthetized by an intraperitoneal injection of $10 \%$ urethane $(2 \mathrm{ml} / 100 \mathrm{~g}$ b.w.). When a sufficient level of anesthesia was achieved, a 2-cm-long polyethylene tube $(2.00 \mathrm{~mm})$ was inserted into the trachea. A polyethylene catheter PE-10 was inserted into the femoral vein for administration of experimental drugs.

\section{Tissue preparation and collection of samples}

At the end of the experimental period, the animals were euthanized. The lungs were surgically removed and cleaned of extraneous tissue. They were rinsed with cold isotonic saline, dried by blotting between two pieces of filter paper and weighed on an electronic balance to estimate lungs edema. The lungs were stored at $-80{ }^{\circ} \mathrm{C}$ for further measurement of their oxidative parameters and TNF- $\alpha$ level.

\section{Preparation of homogenates}

An accurately-weighed portion of the lungs $(50 \mathrm{mg})$ was homogenized in either $0.15 \mathrm{M} \mathrm{KCl}$ for estimation of lipid peroxidation and concentration of $\mathrm{H}_{2} \mathrm{O}_{2}$ or $5 \%$ SSA for estimation of glutathione or HEPES buffer for estimation of TNF- $\alpha$ level. The resulting supernatant was immediately used for biochemical analyses.

\section{Measurement of TBARS in the lungs homogenates}

To determine the degree of oxidative damage in the lungs, lipid peroxidation was measured in lungs homogenates. The lipid peroxidation product content in lungs homogenates was assayed as TBARS, previously described by Yagi (1998). Briefly, $50 \mathrm{mg}$ of the lungs tissue was homogenized with $2 \mathrm{ml}$ of $1.15 \%$ potassium chloride. Then, $4 \mathrm{ml}$ of $0.25 \%$ hydrochloric acid containing $0.375 \%$ thiobarbituric acid (TBA), $15 \%$ trichloroacetic acid (TCA) and $0.015 \%$ butylated hydroxytoluene (BHT) were added. The samples were boiled for $30 \mathrm{~min}$ at $100{ }^{\circ} \mathrm{C}$ in tightly closed tubes. After cooling to $10^{\circ} \mathrm{C}, 2.5 \mathrm{ml}$ of butanol was added to each tube and the samples were centrifuged for $10 \mathrm{~min}$
(3800 g, $20^{\circ} \mathrm{C}$ ). TBA-reactive substances in the butanol layer were measured spectrofluorometrically using an LS-50 Perkin Elmer Luminescence Spectrometer (Norwalk, CT, U.S.A.). Excitation was set at $515 \mathrm{~nm}$ and emission was measured at $546 \mathrm{~nm}$. Sample TBARS concentrations were calculated by the use of the regression equation as follows: $\mathrm{y}=0.43\left(\mathrm{x}-\mathrm{x}_{\mathrm{o}}\right)-2.43$, where $\mathrm{y}=$ TBARS concentration $(\mu \mathrm{M}) ; \mathrm{x}, \quad \mathrm{x}_{\mathrm{o}}=$ fluorescence intensity of the samples and control, respectively (arbitrary units; AU). The regression equation was prepared from triplicate assays of six increasing concentrations of tetramethoxypropane (range 0.01-50 $\mu \mathrm{M}$ ) as a standard for TBARS. A mixture of $2 \mathrm{ml}$ of $1.1 \%$ potassium chloride and $4 \mathrm{ml}$ of $0.25 \mathrm{~N}$ hydrochloric acid was used as a control. Finally, the results were calculated for $50 \mathrm{mg}$ of the lungs tissue.

\section{Measurement of $\mathrm{H}_{2} \mathrm{O}_{2}$ in the lungs homogenates}

The lungs tissue fragments were washed in icecold saline and stored at $-80{ }^{\circ} \mathrm{C}$ for no longer than 2 weeks. Generation of $\mathrm{H}_{2} \mathrm{O}_{2}$ in lungs homogenates was determined according to Ruch et al. (1983). Briefly, $50 \mathrm{mg}$ of the lungs tissue fragments were homogenized with $2 \mathrm{ml}$ of $1.15 \%$ potassium chloride. Then, $10 \mu \mathrm{l}$ aliquot of tissue homogenate was mixed with $90 \mu \mathrm{l}$ of PBS ( $\mathrm{pH} 7.0$ ) and $100 \mu \mathrm{l}$ of horseradish peroxidase (1 U/ml) containing $400 \mu \mathrm{mol}$ homovanilic acid (HRP + HVA assay) or with $90 \mu \mathrm{l}$ of PBS and $100 \mu \mathrm{l}$ of $1 \mathrm{U} / \mathrm{ml}$ horseradish peroxidase only (HRP assay). Both homogenates were incubated for $60 \mathrm{~min}$ at $37^{\circ} \mathrm{C}$. Subsequently, $300 \mu \mathrm{l}$ of PBS and $125 \mu \mathrm{l}$ of $0.1 \mathrm{M}$ glycine - NaOH buffer (pH 12.0) with 25 mM EDTA were added to each homogenate sample. Excitation was set at $312 \mathrm{~nm}$ and emission was measured at $420 \mathrm{~nm}$ (Perkin Elmer Luminescence Spectrometer, Beaconsfield UK). Readings were converted into $\mathrm{H}_{2} \mathrm{O}_{2}$ concentration using the regression equation: $\mathrm{y}=0.0361 \mathrm{x}-0.081$, where $\mathrm{y}=\mathrm{H}_{2} \mathrm{O}_{2}$ concentration in homogenate $(\mu \mathrm{M}) ; \mathrm{x}=$ intensity of light emission at $420 \mathrm{~nm}$ for HRP + HVA assay reduced by HRP assay emission (arbitrary units, AU). The regression equation was prepared from three series of calibration experiments with 10 increasing $\mathrm{H}_{2} \mathrm{O}_{2}$ concentrations (range 10-1,000 $\mu \mathrm{M}$ ). The lowest $\mathrm{H}_{2} \mathrm{O}_{2}$ detection was $0.1 \mathrm{nM}$, with intraassay variability not exceeding $2 \%$.

\section{Determination of GSH levels}

Total glutathione (GSHt), reduced glutathione (GSH) and oxidized glutathione (GSSG) were measured 
in the lungs homogenates. Briefly, the lungs were homogenized in cold $5 \%$ 5-SSA and centrifuged $\left(10000 \mathrm{~g}, 10 \mathrm{~min}, 4{ }^{\circ} \mathrm{C}\right)$. The GSHt content of the supernatant was measured in a $1 \mathrm{ml}$ cuvette containing $0.7 \mathrm{ml}$ of $0.2 \mathrm{mM}$ NADPH, $0.1 \mathrm{ml}$ of $0.6 \mathrm{mM}$ DTNB, $0.15 \mathrm{ml}$ of $\mathrm{H}_{2} \mathrm{O}$ and $50 \mu \mathrm{l}$ of the sample. The cuvette with the mixture was incubated for $5 \mathrm{~min}$ at $37^{\circ} \mathrm{C}$ and then supplemented with $0.6 \mathrm{U} / 1$ of GR. The reaction kinetics was followed spectrophotometrically at $412 \mathrm{~nm}$ for $5 \mathrm{~min}$ by monitoring the increase in absorbance.

GSSG concentration was determined in supernatant aliquots by the same method after optimization of $\mathrm{pH}$ to 6-7 with $1 \mathrm{M}$ TEA and derivatization of endogenous GSH with 2-vinylpyridine (v:v). The reduced glutathione level in the supernatant was calculated as the difference between GSHt and GSSG. The increments in absorbance at $412 \mathrm{~nm}$ were converted to GSHt and GSSG concentrations using a standard curve (3.2-500 $\mu \mathrm{M}$ glutathione for GSHt and 0.975-62 M for GSSG). The results were expressed in $\mu \mathrm{M}$.

\section{Tumor necrosis factor-assay}

TNF- $\alpha$ in the lungs tissues was assayed by specific enzyme linked immunosorbent assay using a commercially-available ELISA test kit (R\&D Systems) containing a monoclonal antibody specific for rat TNF- $\alpha$. The results were read using a TEK Instruments EL340 BIO-spectrophotometer (Winooski VT, USA) $(\lambda=45 \mathrm{~nm})$. The sensitivity of the kit was $10 \mathrm{pg} / \mathrm{ml}$. The TNF- $\alpha$ concentration was read from standard curves and expressed in $\mathrm{pg} / \mathrm{ml}$.

The experiments were repeated twice.

\section{Statistical analysis}

The results are presented as mean \pm SEM. The statistical analysis was done by ANOVA followed by the Duncan's multiple range test as post-hoc. A p-value less than 0.05 was considered significant.

\section{Results}

Evaluation of lipid peroxidation, $\mathrm{H}_{2} \mathrm{O}_{2}$ and glutathione levels

A significant increase in the homogenate level of a marker of the lipid peroxidation TBARS and $\mathrm{H}_{2} \mathrm{O}_{2}$ level (respectively: $\mathrm{p}<0.001, \mathrm{p}<0.02$ ) was observed in ET-1treated rats in comparison to that in the control rats. A significant decrease in TBARS $(\mathrm{p}<0.01)$ and $\mathrm{H}_{2} \mathrm{O}_{2}$ $(p<0.02)$ levels was observed in rats of the BQ123 and
ET-1-treated group in comparison to rats in the ET-1 group. There was also a significant decrease in lungs TBARS $(p<0.001)$ and $\mathrm{H}_{2} \mathrm{O}_{2}$ levels $(p<0.05)$ in the L-NAME + ET-1-treated group in comparison to the ET-1 group. However, no significant changes in TBARS and $\mathrm{H}_{2} \mathrm{O}_{2}$ levels were observed in BQ788 + ET-1-treated rats compared to those in ET-1-treated rats.

a

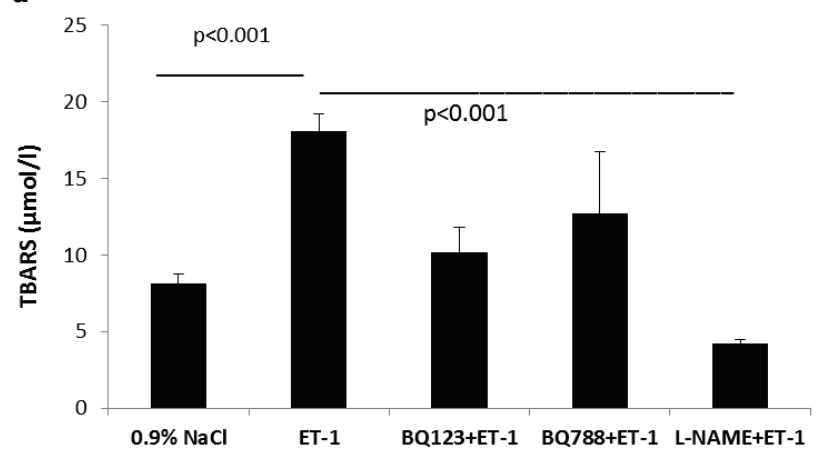

b

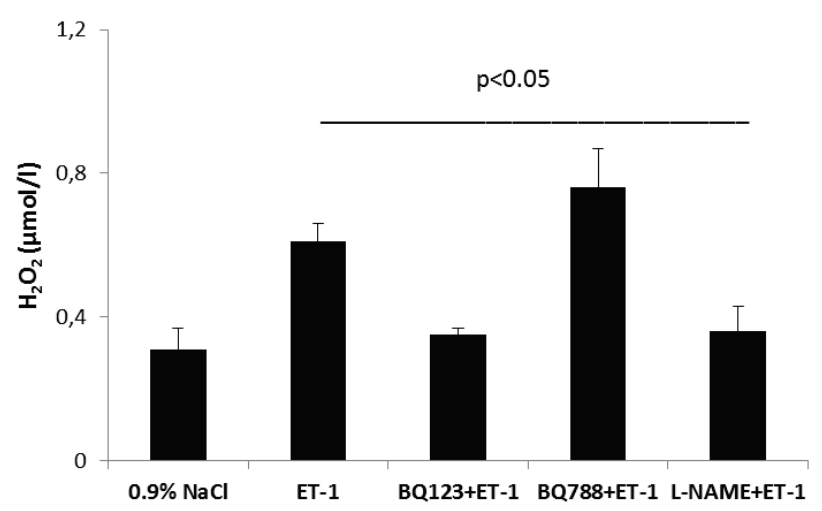

c

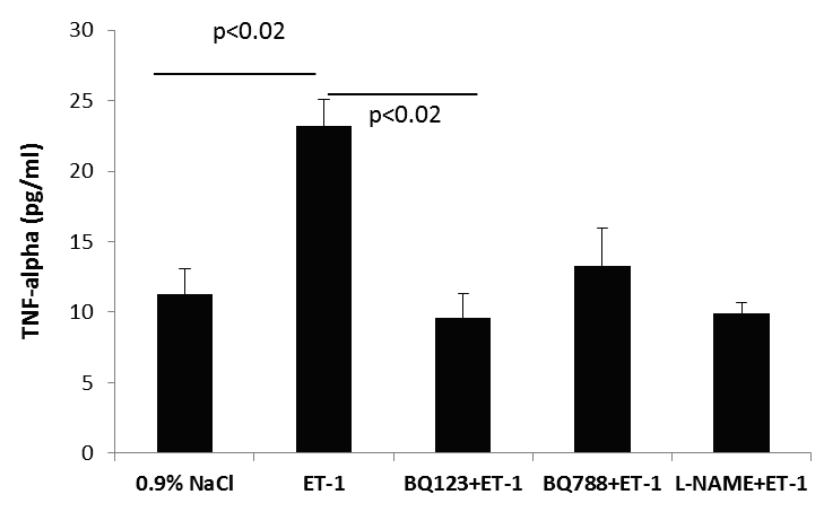

Fig. 1. The influence of endothelin-1 (ET-1), its receptor blockers and L-NAME on the concentrations of: (a) thiobarbituric acid reactive substance (TBARS), (b) hydrogen peroxide $\left(\mathrm{H}_{2} \mathrm{O}_{2}\right)$, and (c) TNF-a levels in lungs. ET-1 $(3 \mu \mathrm{g} / \mathrm{kg}$ ) was injected $30 \mathrm{~min}$ after saline administration. BQ123 - endothelin-A receptor blocker $(1 \mathrm{mg} / \mathrm{kg}), \quad B Q 788$ - endothelin-B receptor blocker $(3 \mathrm{mg} / \mathrm{kg})$, and L-NAME - N $\omega$-Nitro-L-arginine methyl ester hydrochloride $(5 \mathrm{mg} / \mathrm{kg}$ ) were administered $30 \mathrm{~min}$ prior to the injection of ET-1. The results are mean \pm SEM. The data was statistically evaluated by one-way ANOVA. 
Levels of GSHt and GSH in the lungs of ET-1 treated animals were significantly lower than those of the control group $(\mathrm{p}<0.01)$. BQ123 treatment significantly improved levels of GSHt and GSH (respectively: $\mathrm{p}<0.001, \mathrm{p}<0.02)$ as compared to ET-1 treated rats. Also BQ788 and L-NAME treatment cause significant changes in GSHt and GSH levels - respectively: $p<0.001, p<0.05$ and $\mathrm{p}<0.001, \mathrm{p}<0.05$ (Fig. 2a).

There was a significant decrease in lungs GSH/GSSG ratio in the ET-1-treated group in comparison to the control group $(\mathrm{p}<0.001)$. Treatment with BQ123 and BQ788 before ET-1 administration was resulting in an increase in the GSH/GSSG ratio compared with the ET-1 group $(\mathrm{p}<0.05)$. L-NAME did not lead to a significant increase in GSH/GSSG when compared with ET-1 group (Fig. 2b)

\section{a}

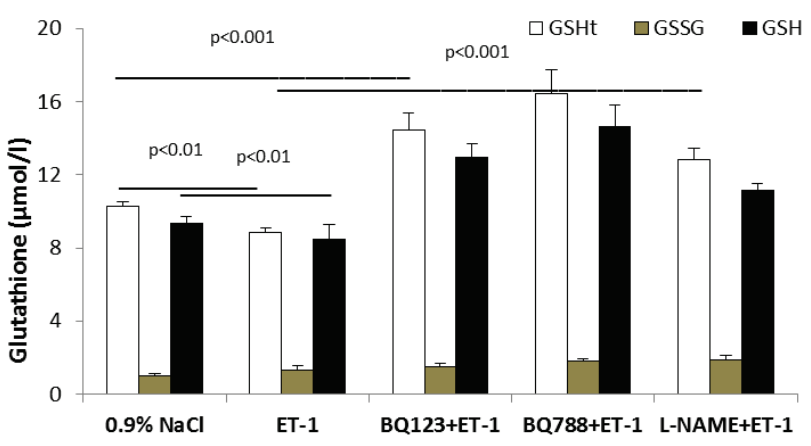

b

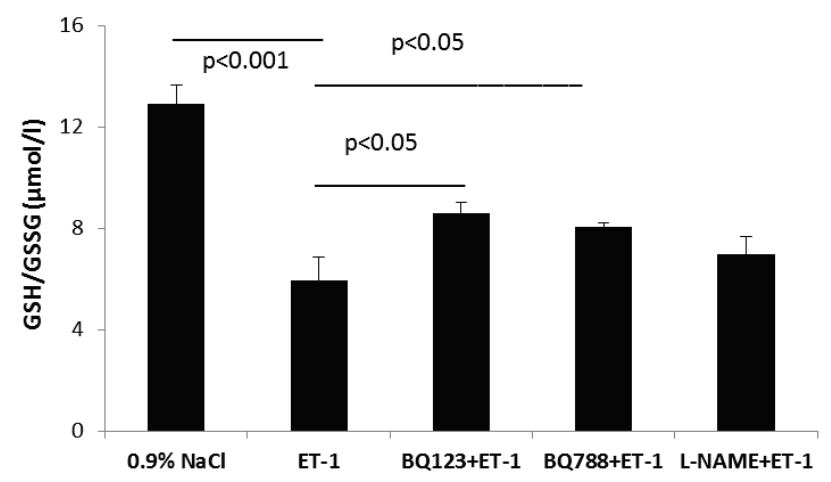

Fig. 2. Changes in (a) the total glutathione (GSHt), oxidized glutathione (GSSG), reduced glutathione (GSH) and (b) reduced to oxidized glutathione ratio (GSH/GSSG) in experimental groups of rats. ET-1 - endothelin $1(3 \mu \mathrm{g} / \mathrm{kg})$ was injected $30 \mathrm{~min}$ after saline administration. BQ123 - endothelin-A receptor blocker $(1 \mathrm{mg} / \mathrm{kg}), B Q 788$ - endothelin-B receptor blocker $(3 \mathrm{mg} / \mathrm{kg})$, and L-NAME - N $\omega$-Nitro-L-arginine methyl ester hydrochloride $(5 \mathrm{mg} / \mathrm{kg}$ ) were administered $30 \mathrm{~min}$ prior to the injection of ET- 1 . The results are mean \pm SEM. The data was statistically evaluated by one-way ANOVA.

\section{Evaluation of TNF- $\alpha$}

Figure 1c shows that following ET-1 administration, the level of TNF- $\alpha$ was markedly increased in lungs homogenates when compared to the control group $(\mathrm{p}<0.02)$. However, a significant decrease in TNF- $\alpha$ level was observed in BQ123 + ET-1-treated group in comparison to that in ET-1-treated rats $(\mathrm{p}<0.02)$. Significant change was found in L-NAME + ET-1treated rats in comparison to ET-1-treated rats $(\mathrm{p}<0.01)$. The level of TNF- $\alpha$ was decreased also in the BQ788 group. However, no significant changes were observed.

\section{Discussion}

In the present study, we have demonstrated that ET-1 administration increased the levels of TBARS, $\mathrm{H}_{2} \mathrm{O}_{2}$, and TNF- $\alpha$ and decreased the glutathione level in the lungs homogenates. These parameters were improved significantly after the ETA receptor blockade, whereas the ETB receptor blockade had a slight effect. Similarly, in accordance with our results, several other studies have reported that ET-1 produces ROS (Elmarakby et al. 2008, Lee et al. 2010, Li et al. 2003a). Increased ROS generation in our study is supported by the increased TBARS lungs levels, which reflects an elevation of enzymatic lipoperoxidation. Lipid peroxidation of unsaturated fatty acids impairs cell membrane fluidity and alters activity of membrane-bound enzymes and receptors. The high level of the lipid peroxidation marker TBARS reflects ROS-mediated damage of cells. The toxic effect of ROS on cells in our study was indicated by the enhanced level of $\mathrm{H}_{2} \mathrm{O}_{2}$ in lungs homogenates. $\mathrm{H}_{2} \mathrm{O}_{2}$ is produced from superoxide anion by superoxide dismutase (SOD). $\mathrm{H}_{2} \mathrm{O}_{2}$ is more toxic than oxygenderived free radicals and is capable of producing the most toxic hydroxyl radical ( $\mathrm{OH})$. Catalase (CAT) and peroxidase (GPx) convert $\mathrm{H}_{2} \mathrm{O}_{2}$ to water and oxygen. The increase in $\mathrm{H}_{2} \mathrm{O}_{2}$ level in our study may be caused by enhanced activity of SOD and reduced CAT activity in the lungs tissue after ET-1 administration as it has been indicated in hemorrhagic rats (Korzonek-Szlacheta and Gwóźdź 2007).

Glutathione is a primary non-enzymatic intracellular antioxidant. It mainly appears in a reduced state (GSH) but is oxidized to disulfide glutathione (GSSG) in order to inactivate free radicals. In this study, the decreased glutathione level and GSH/GSSG ratio seen after ET-1 administration reflect the antioxidant status of the tissue and was associated with the increased TBARS 
level. These results are in line with previous reports, which demonstrated that ET-1 may lead to oxidative stress by reducing glutathione, diminishing the antioxidant GSH/GSSG ratio and stimulating lipid peroxidation in a time-dependent manner (Viswanatha Swamy et al. 2011).

TNF- $\alpha$ is an inflammatory cytokine that acts mainly through the activation of nuclear factor $-\mathrm{kB}$ (NF-kB) (Elmarakby et al. 2008). In experimental models of inflammatory diseases, NF-kB is activated and regulates the expression of genes involved in tissue inflammation such as TNF- $\alpha$ (Therrien et al. 2012). ROS can increase gene expression of this inflammatory mediator from macrophages, alveolar and bronchial epithelial cells. Generation of TNF- $\alpha$ at high levels leads to the development of inflammatory responses that are hallmarks of many pulmonary diseases (e.g. asthma, chronic bronchitis - $\mathrm{CB}$, chronic obstructive pulmonary disease - COPD, acute lung injury - ALI and acute respiratory distress syndrome - ARDS). In our study, the ET-1 administration resulted in an increase in TNF- $\alpha$ level in the lungs tissue. These findings are in agreement with those showing that ET-1 stimulates monocytes and macrophages to release TNF- $\alpha$ and increased plasma or tissue concentration of TNF- $\alpha$ (Jesmin et al. 2011, Tonari et al. 2012).

In the present study we observed that the decreased TBARS and $\mathrm{H}_{2} \mathrm{O}_{2}$ levels in ET-1 challenged rats were significantly ameliorated by BQ123 or L-NAME pretreatment, consistent with our previous report (Piechota-Polanczyk et al. 2012). This shows that BQ123 prevents lipid peroxidation. These findings are in accordance with studies of other investigators who observed reduction in lipid peroxidation in different organs after blocking ETA (Briyal et al. 2012, Goyal et al. 2010, Ozdemir et al. 2006), or ETB receptors (Dai et al. 2004, Leonard et al. 2011, Li et al. 2010). The decrease in $\mathrm{H}_{2} \mathrm{O}_{2}$ level in our study indicates the decrease in ROS formation and lipid peroxidation in the lungs tissue. It was shown that the use of ETA receptor antagonist provided beneficial effects in chronic heart failure as evidenced by a reduction of infarct size, improved reperfusion, coronary flow or protection during ischemic/reperfusion injury (Ozdemir et al. 2006). In our study, BQ123 not only prevented ET-1-induced lungs injury but also increased the GSH levels and GSH/GSSG ratio. The increase in reduced glutathione and GSH/GSSG ratio within lungs tissue demonstrates the ability of ET-1 receptor antagonist to combat oxidative damage. These results are consistent with previous reports showing that blockade of ETA receptor increases glutathione level in heart (Ozdemir et al. 2006) and other tissues (Briyal et al. 2012). In our study pretreatment with BQ788 had significant influence on the level of GSH in the lungs tissue and caused the increased GSH/GSSG ratio. However, other authors obtained that pretreatment with BQ788 had slight influence on the level of GSH in the brain but caused the increased GSH/GSSG ratio (Briyal et al. 2012). Studies on blocking the ETB receptors are ambiguous. Wedgwood et al. (2005) demonstrated that ETB receptor antagonist (RES-701-3) increased production of $\mathrm{H}_{2} \mathrm{O}_{2}$ in the cell culture of the pulmonary artery smooth muscle, but not in the endothelial cells. However, results of some study indicated that the administration of ETB receptor blocker - BQ788 reduces the production of reactive oxygen species in the various tissues (Dai et al. 2004, PiechotaPolanczyk et al. 2012). The use of ETB receptor blockers binds both to the preferred (a decrease in contractility of the blood vessels) as well as harmful (worsening hemodynamics and renal system) effects. (Tostes and Muscara 2005). ETB receptors are involved in vascular remodeling after injury so their blockade impairs this process (Murakoshi et al. 2002). Blockade of the ETB receptor is also associated with impaired clearance of ET-1 in the pulmonary vasculature. Moreover, development of hypertension after chronic administration of ETB receptor antagonist was observed (the administration of the ETA receptor blocker abolished this effect) (Reinhart et al. 2002).

In the current study we found that TNF- $\alpha$ levels were significantly lower in the BQ123 and L-NAMEtreated groups than in the ET-1 group. The decrease in TNF- $\alpha$ level indicates the reduction in lugs inflammation. This result is consistent with other authors who demonstrated diminished TNF- $\alpha$ level after ETA blockade in the different tissues. Tonari et al. (2012) have reported that treatment with BQ123 antagonist of ETA receptors decreased TNF- $\alpha$ in the optic nerve crush. However, Verri et al. (2004) have presented that inhibition of ETB receptors by BQ788 may be beneficial in controlling inflammation hypernociception of diseases in which IL-18 plays a role in their pathogenesis.

In our study, we have shown that inhibition of NO synthesis by L-NAME, a compound inhibiting both the constitutive and inducible $\mathrm{NO}$ synthases, led to a reduction of TBARS and $\mathrm{H}_{2} \mathrm{O}_{2}$ concentrations in lung homogenates. However, Saravanakumar and Raja (2011) 
have showed an increase in lipid peroxidation in plasma rats after L-NAME administration. Ramprasath et al. (2012) have reported an increase in the TBARS level in left ventricles after L-NAME administration in diabetic rats. In this study, L-NAME administration resulted in a slight increase in the GSHt and GSH concentration and enhanced the GSH/GSSG ratio as compared to the ET-1 group. However, other authors demonstrated decrease in glutathione level and antioxidant enzymes (SOD, CAT) in the plasma (Saravanakumar and Raja 2011) and in the heart (Ramprasath et al. 2012) after L-NAME administration. These results suggest that other alternative signaling pathways different than NOS take part in the ROS generation.

We have also found that inhibition of NO synthase by L-NAME, significantly ameliorated the lungs inflammation (assessed by tissue TNF- $\alpha$ level) caused by exogenous ET-1 administration. It is believed that TNF- $\alpha$ initiates the inflammatory reaction by releasing other inflammatory mediators, increasing the expression of cell adhesion factor, and promoting neutrophil adhesion to endothelial cells. Some other studies have shown that blockade of NOS with L-NAME resulted in significant increase in TNF- $\alpha$ in heart (Sojitra et al. 2012), liver (Guo et al. 2011), and aortas (Sukhanov et al. 2011). Conversely, L-NAME had a protective effect against injury induced by the deposition of immune complexes (Mulligan et al. 1992) and against alveolar injury caused by smoke inhalation (Ischiropoulos et al. 1994).

Moreover, some studies on ET-1 treated rats demonstrated a significant increase in the heart/body weight ratio. This may be attributed to albumin extravasculation in the vascular bed (Filep et al. 1994,
1996) increase in vascular permeability and myocardial water content (Murray et al. 2004) or with increased VEGF release and TNF- $\alpha$ in the heart after ET-1 injection (Shimojo et al. 2007). This finding clearly demonstrated the development of heart injury due to acute inflammation and interstitial edema in rat heart. Reduced endothelin-1 induced increase in HW/BW ratio may be associated with significant reduction in ROS generation and inflammatory response or decreased VEGF content in the heart (Goyal et al. 2010, Labrutto et al. 2007, Oz et al. 2012, Shimojo et al. 2007). Recently reports have demonstrated that the inhibition of nitric oxide synthase (NOS) activity by L-NAME caused increase in HW/BW (Sojitra et al. 2012).

\section{Conclusions}

We have demonstrated that ET-1 induced oxidative stress in lungs is mediated by ETA receptors. ETA receptor blockage inhibited free radical generation and TNF- $\alpha$ and ameliorated antioxidant properties; ETB receptor blockage was no effective. Moreover, NOS play role in generation of ROS in the lungs because L-NAME administration significantly reduced the TBARS, $\mathrm{H}_{2} \mathrm{O}_{2}$ and TNF- $\alpha$ level and slightly increased the GSH level.

\section{Conflict of Interest}

There is no conflict of interest.

\section{Acknowledgements}

This study was supported by grant 503/0-079-03/503-01 from the Medical University of Lodz.

\section{References}

BRIYAL S, GULATI K, GULATI A: Repeated administration of exendin-4 reduces focal cerebral ischemia-induced infarction in rats. Brain Res 1427: 23-34, 2012.

DAI X, GALLIGAN JJ, WATTS SW, FINK GD, KREULEN DL: Increased $\mathrm{O}_{2}{ }^{\circ-}$ production and upregulation of ETB Receptors by sympathetic neurons in DOCA-salt hypertensive rats. Hypertension 43: 1048-1054, 2004.

ELMARAKBY AA, QUIGLEY JE, IMIG JD, POLLOCK JS, POLLOCK DM: TNF-alpha inhibition reduces renal injury in DOCA-salt hypertensive rats. Am J Physiol Regul Integr Comp Physiol 294: R76-R83, 2008.

FILEP JG, FOURNIER A, FÖLDES-FILEP E: Endothelin-1-induced myocardial ischaemia and oedema in the rat: involvement of the ETA receptor, platelet-activating factor and thromboxane A2. Br J Pharmacol 112: 963-971, 1994.

FILEP JG, SKROBIK Y, FOURNIER A, FÖLDES-FILEP E: Effects of calcium antagonists on endothelin-1-induced myocardial ischaemia and oedema in the rat. Br J Pharmacol 118: 893-900, 1996.

GALIE N, MANES A, BRANZI A: The endothelin system in pulmonary arterial hypertension. Cardiovasc Res 61: 227-237, 2004. 
GOYAL SN, BHARTI S, ARORA S, GOLECHHA M, ARYA DS: Endothelin receptor antagonist BQ-123 ameliorates myocardial ischemic-reperfusion injury in rats: a hemodynamic, biochemical, histopathological and electron microscopic evidence. Biomed Pharmacotherapy 64: 639-646, 2010.

GUO JY, YANG T, SUN XG, ZHOU NY, LI FS, LONG D, LIN T, LI PY, FENG L: Ischemic postconditioning attenuates liver warm ischemia-reperfusion injury through Akt-eNOS-NO-HIF pathway. J Biomed Sci 18: 79, 2011.

HASSOUN PM, YU FS, ZULUETA JJ, WHITE AC, LANZILLO JJ: Effect of nitric and cell redox status on the regulation of endothelial cell xanthine dehydrogenase. Am J Physiol 268: L809-L817, 1995.

HSU JH, OISHI P, WISEMAN DA, HOU Y, CHIKOVANI O, DATAR S, SAJTI E, JOHENGEN MJ, HARMON C, BLACK SM, FINEMAN JR: Nitric oxide alterations following acute ductal constriction in the fetal lamb: a role for superoxide. Am J Physiol Lung Cell Mol Physiol 298: L880-L887, 2010.

ISCHIROPOULOS H, MENDIGUREN I, FISHER D, FISHER A, THOM S: Role of neutrophils and nitric oxide in lungalveolar injury from smoke inhalation. Am J Respir Crit Care Med 150: 337-341, 1994.

JESMIN S, YAMAGUCHI N, ZAEDI S, NUSRAT SULTANA SN, IWASHIMA Y, SAWAMURA A, GANDO S: Time-dependent expression of endothelin-1 in lungs and the effects of TNF- $\alpha$ blocking peptide on acute lung injury in an endotoxemic rat model. Biomed Res 32: 9-17, 2011.

KORZONEK-SZLACHETA I, GWÓŹDŹ B: Effects of endothelin-1 on prevention of microvascular endothelium injuries in hemorrhagic shock in rats. Pharmacol Rep 59: 98-106, 2007.

LABRUTTO F, PERNOW J, YANG J, VAAGE J, VALEN G: Small skin burn injury reduces cardiac tolerance to ischemia via a tumor necrosis factor alpha-dependent pathway. Burns 33: 606-612, 2007.

LAPLANTE MA, WU R, MOREAU P, DE CHAMPLAIN J: Endothelin mediates superoxide production in angiotensin II-induced hypertension in rats. Free Radic Biol Med 38: 589-596, 2005.

LEE JJ, HUNG CC, TSAI JC, CHEN HC: Endothelin-1 enhances superoxide and prostaglandin E2 production of isolated diabetic glomeruli. Kaohsiung J Med Sci 26: 350-356, 2010.

LEONARD MG, BRIYAL S, GULATI A: Endothelin B receptor agonist, IRL-1620, reduces neurological damage following permanent middle cerebral artery occlusion in rats. Brain Res 1420: 48-58, 1995.

LI L, FINK GD, WATTS SW, NORTHCOTT CA, GALLIGAN JJ, PAGANO PJ, CHEN AF: Endothelin-1 increases vascular superoxide via endothelin(A)-NADPH oxidase pathway in low-renin hypertension. Circulation 107: 1053-1058, 2003a.

LI L, WATTS SW, BANES AK, GALLIGAN JJ, FINK GD, CHEN AF: NADPH oxidase-derived superoxide augments endothelin-1-induced venoconstriction in mineralocorticoid hypertension. Hypertension 42: 316-321, 2003 b.

LI Y, LEVESQUE LO, ANAND-SRIVASTAVA MB: Epidermal growth factor receptor transactivation by endogenous vasoactive peptides contributes to hyperproliferation of vascular smooth muscle cells of SHR. Am J Physiol Heart Circ Physiol 299: H1959-H1967, 2010.

LOOMIS ED, SULLIVAN JC, OSMOND DA, POLLOCK DM, POLLOCK JS: Endothelin mediates superoxide production and vasoconstriction through activation of NADPH oxidase and uncoupled nitric-oxide synthase in the rat aorta. J Pharmacol Exp Ther 315: 1058-1064, 2005.

LUND AK, PETERSON SL, TIMMINS GS, WALKER MK: Endothelin-1-mediated increase in reactive oxygen species and NADPH Oxidase activity in hearts of aryl hydrocarbon receptor (AhR) null mice. Toxicol Sci 88: 265-273, 2005.

MULLIGAN MS, WARREN JS, SMITH CW, ANDERSON DC, YEH CG, RUDOLPH AR, WARD PA: Lung injury after deposition of $\operatorname{IgA}$ immune complexes: requirements for CD18 and L-arginine. J Immunol 148: 3086-3092, 1992.

MURAKOSHI N, MIYAUCHI T, KAKINUMA Y, OHUCHI T, GOTO K, YANAGISAWA M, YAMAGUCHI I: Vascular endothelin-B receptor system in vivo plays a favorable inhibitory role in vascular remodeling after injury revealed by endothelin-B receptor-knockout mice. Circulation 106: 1991-1998, 2002.

MURRAY DB, GARDNER JD, BROWER GL, JANICKI JS: Endothelin-1 mediates cardiac mast cell degranulation, matrix metalloproteinase activation, and myocardial remodeling in rats. Am J Physiol Heart Circ Physiol 287: H2295-H2299, 2004. 
OZ HS, LU Y, VERA-PORTOCARRERO LP, GE P, SILOS-SANTIAGO A, WESTLUND KN: Gene expression profiling and endothelin in acute experimental pancreatitis. World J Gastroenterol 18: 4257-4269, 2012.

OZDEMIR R, PARLAKPINAR H, POLAT A, COLAK C, ERMIS N, ACET A: Selective endothelin a (ETA) receptor antagonist (BQ-123) reduces both myocardial infarct size and oxidant injury. Toxicology 219, 142-149, 2006.

PIECHOTA-POLANCZYK A, KLENIEWSKA P, GORĄCA A: The influence of ETA and ETB receptor blockers on LPS-induced oxidative stress and NF-кB signaling pathway in heart. Gen. Physiol. Biophys 31, 271-278, 2012.

RAMPRASATH T, KUMAR PH, PUHARI SS, MURUGAN PS, VASUDEVAN V, SELVAM GS: L-arginine ameliorates cardiac left ventricular oxidative stress by upregulating eNOS and Nrf2 target genes in alloxaninduced hyperglycemic rats. Biochem Biophys Res Commun 428: 389-394, 2012.

REINHART GA, PREUSSER LC, BURKE SE, WESSALE JL, WEGNER CD, OPGENORTH TJ, COX BF: Hypertension induced by blockade of ET(B) receptors in conscious nonhuman primates: role of ET(A) receptors. Am J Physiol Heart Circ Physiol 283: H1555-H1561, 2002.

RUCH W, COOPER PH, BAGGIOLINI M: Assay of $\mathrm{H}_{2} \mathrm{O}_{2}$ production by macrophages and neutrophils with homovanillic acid and horse-radish peroxidase. J Immunol Methods 63: 347-357, 1983.

SARAVANAKUMAR M, RAJA B: Veratric acid, a phenolic acid attenuates blood pressure and oxidative stress in L-NAME induced hypertensive rats. Eur J Pharmacol 67: 87-94, 2011.

SCHIFFRIN EL: Role of endothelin-1 in hypertension and vascular disease. Am J Hypertens 14: 83S-89S, 2001.

SCHULZ R, T. RASSAF T, MASSION PB, KELM M, BALLIGAND JL: Recent advances in the understanding of the role of nitric oxide in cardiovascular homeostasis. Pharmacol Ther 108: 225-256, 2005.

SEDEEK MH, LLINAS MT, DRUMMOND H, FORTEPIANI L, ABRAM SR, ALEXANDER BT, RECKELHOFF JF, GRANGER JP: Role of reactive oxygen species in endothelin-induced hypertension. Hypertension 42: 806$810,2003$.

SHIMOJO N, JESMIN S, ZAEDI S, OTSUKI T, MAEDA S, YAMAGUCHI N, AONUMA K, HATTORI Y, MIYAUCHI T: Contributory role of VEGF overexpression in endothelin-1-induced cardiomyocyte hypertrophy. Am J Physiol Heart Circ Physiol 293: H474-H481, 2007.

SOJITRA B, BULANI Y, PUTCHA UK, KANWAL A, GRUPTA P, KUNCHA M, BANERJEE SK: Nitric oxide synthase inhibition abrogates hydrogen sulfide-induced cardioprotection in mice. Mol Cell Biochem 360: 61-69, 2012.

SUKHANOV S, HIGASHI Y, SHAI SY, BLACKSTOCK C, GALVEZ S, VAUGHN C, TITTERINGTON J, DELAFONTAINE P: Differential requirement for nitric oxide in IGF-1-induced anti-apoptotic, anti-oxidant and anti-atherosclerotic effects. FEBS Lett 585: 3065-3072, 2011.

SULLIVAN JC, POLLOCK JS, POLLOCK DM: Superoxide-dependent hypertension in male and female endothelin B receptor-deficient rats. Exp Biol Med 231: 818-823, 2006.

THAKALI K, DEMEL SL, FINK GD, WATTS SW: Endothelin-1-induced contraction in veins is independent of hydrogen peroxide. Am J Physiol Heart Circ Physiol 289: H1115-H1122, 2005.

THERRIEN FJ, AGHARAZII M, LEBEL M, LARIVIČRE R: Neutralization of tumor necrosis factor-alpha reduces renal fibrosis and hypertension in rats with renal failure. Am J Nephrol 36: 151-161, 2012.

TONARI M, KURIMOTO T, HORIE T, SUGIYAMA T, IKEDA T, OKU H: Blocking endothelin-B receptors rescues retinal ganglion cells from optic nerve injury through suppression of neuroinflammation. Invest Opthalmol Vis Sci 53: 3490-3500, 2012.

TOSTES RC, MUSCARA MN: Endothelin receptor antagonists: another potential alternative for cardiovascular diseases. Curr Drug Targets Cardiovasc Haematol Disord 5: 287-301, 2005.

VERRI WA JR, SCHIVO IR, CUNHA TM, LIEW FY, FERREIRA SH, CUNHA FQ: Interleukin-18 induces mechanical hypernociception in rats via endothelin acting on ETB receptors in a morphine-sensitive manner. J Pharmacol Exp Therap 310: 710-717, 2004.

VISWANATHA SWAMY AH, WANGIKAR U, KOTI BC, THIPPESWAMY AH, RONAD PM, MANJULA DV: Cardioprotective effect of ascorbic acid on doxorubicin-induced myocardial toxicity in rats. Indian J Pharmacol 43: 507-511, 2011.

WEDGWOOD S, DETTMAN RW, BLACK SM: ET-1 stimulates pulmonary arterial smooth muscle cell proliferation via induction of reactive oxygen species. Am J Physiol Lung Cell Mol Physiol 281: L1058-L1067, 2001. 
YAGI K: Simple assay for the level of total lipid peroxides in serum or plasma. Methods Mol Biol 108: 101-106, 1998.

YAO L, KOBORI H, RAHMAN M, SETH DM, SHOKOJI T, FAN Y, ZHANG GX, KIMURA S, ABE Y, NISHIYAMA A: Olmesartan improves endothelin-induced hypertension and oxidative stress in rats. Hypertens Res 27: 493-500, 2004.

ZHANG Y, TOCCHETTI CG, KRIEG T, MOENS AL: Oxidative and nitrosative stress in the maintenance of myocardial function. Free Radical Biol Med 53: 1531-1540, 2012. 